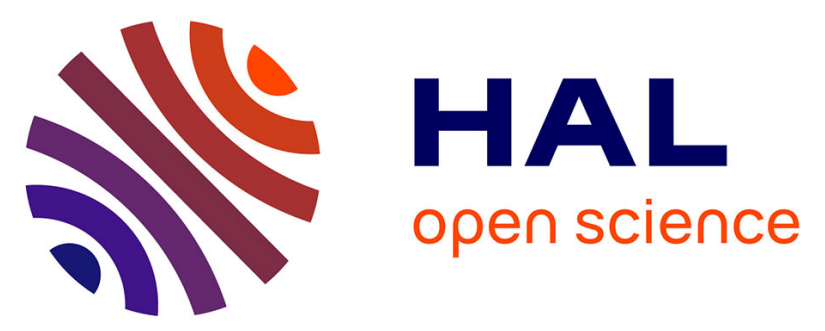

\title{
Potential synergic effect between MOR and BEA zeolites in NOx SCR with methane: A dual bed design approach
}

Acácio Nobre Mendes, Alexis Matynia, Alain Toullec, Sandra Capela, M.Filipa Ribeiro, Carlos Henriques, Patrick da Costa

\section{- To cite this version:}

Acácio Nobre Mendes, Alexis Matynia, Alain Toullec, Sandra Capela, M.Filipa Ribeiro, et al.. Potential synergic effect between MOR and BEA zeolites in NOx SCR with methane: A dual bed design approach. Applied Catalysis A : General, 2015, 506, pp.246-253. 10.1016/j.apcata.2015.09.005 . hal01198667

\section{HAL Id: hal-01198667 \\ https: / hal.sorbonne-universite.fr/hal-01198667}

Submitted on 14 Sep 2015

HAL is a multi-disciplinary open access archive for the deposit and dissemination of scientific research documents, whether they are published or not. The documents may come from teaching and research institutions in France or abroad, or from public or private research centers.
L'archive ouverte pluridisciplinaire HAL, est destinée au dépôt et à la diffusion de documents scientifiques de niveau recherche, publiés ou non, émanant des établissements d'enseignement et de recherche français ou étrangers, des laboratoires publics ou privés. 


\section{Potential synergic effect between MOR and BEA zeolitesin $\mathrm{NO}_{\mathrm{x}} \mathrm{SCR}$ with methane: a dual bed design approach}

Acácio Nobre Mendes ${ }^{1,2^{*}}$, Alexis Matynia ${ }^{2,3}$, Alain Toullec ${ }^{2,3}$, Sandra Capela ${ }^{4}$, M. Filipa Ribeiro $^{1}$, Carlos Henriques ${ }^{1}$, Patrick Da Costa ${ }^{2,3}$

${ }^{1}$ Centro de Química Estrutural, Instituto Superior Técnico, Universidade de Lisboa. Av. Rovisco Pais, 1049-001 Lisboa, Portugal.

${ }^{2}$ Sorbonne Universités, UPMC,Univ. Paris 06, UMR 7190, Institut Jean le Rond d'Alembert, F-75005, Paris, France.

${ }^{3}$ CNRS, UMR 7190, Institut Jean le Rond d'Alembert, F-78210, Saint-Cyr l'Ecole, France.

${ }^{4}$ ENGIE, Research and Innovation Department, CRIGEN, 361 avenue du Président Wilson, 93211 Saint Denis La Plaine cedex France.

* Correspondingauthor: acacio.mendes@tecnico.ulisboa.pt

Graphical abstract

\section{Highlights}

- MOR and BEA zeolite catalysts containing Pd and Ce were prepared in a similar way.

- Characterisation evidenced different metal species in each catalyst.

- Catalyst exhibited different $\mathrm{NO}$ oxidation and $\mathrm{NO}_{\mathrm{x}} \mathrm{CH}_{4}-\mathrm{SCR}$ performances.

- Dual bed configuration revealed a potential synergic effect for $\mathrm{NO}_{\mathrm{x}} \mathrm{CH}_{4}-\mathrm{SCR}$. 


\begin{abstract}
The selective catalytic reduction of $\mathrm{NO}_{\mathrm{x}}$ with methane $\left(\mathrm{NO}_{\mathrm{x}} \mathrm{CH}_{4}\right.$-SCR)under lean conditions was investigated with catalysts based on two different zeolite structures (MOR and BEA) containing Pd and Ce. The catalytic performance for NO oxidation to $\mathrm{NO}_{2}$ reaction, considered an important first key step in the $\mathrm{NO}_{\mathrm{x}} \mathrm{CH}_{4}-\mathrm{SCR}$ mechanism, was also assessed.
\end{abstract}

$\operatorname{Pd}(0.3) \mathrm{Ce}(2)-\mathrm{HBEA}$ was found to be very active for NO oxidation but exhibits poor activity for $\mathrm{NO}_{\mathrm{x}} \mathrm{CH}_{4}-\mathrm{SCR}$. Conversely, $\mathrm{Pd}(0.3) \mathrm{Ce}(2)-\mathrm{HMOR}$ presents modest activity for $\mathrm{NO}$ oxidation, compared to $\mathrm{Pd}(0.3) \mathrm{Ce}(2)-\mathrm{HBEA}$, but exhibits mildactivity for $\mathrm{NO}_{\mathrm{x}}$ $\mathrm{CH}_{4}-\mathrm{SCR}$ reaction. Characterisation by $\mathrm{H}_{2}$-TPR, DRS UV-Vis, TEM/EDS and FTIR$\mathrm{CO}$ allowed the identification of palladium stabilised as $\mathrm{Pd}^{2+}$ ions in exchange positions in both monometallic and bimetallic MOR based catalysts, whereas, in BEA catalysts, it is presented as PdOclusters. Cerium is stabilised in $\mathrm{Pd}(0.3) \mathrm{Ce}(2)-\mathrm{HMOR}$ as small $\mathrm{CeO}_{2}$ particles, whereas, in $\mathrm{Pd}(0.3) \mathrm{Ce}(2)-\mathrm{HBEA}$, it is present aslarge clusters.Catalysts were also tested in dual bed configuration, in which $\operatorname{Pd}(0.3) \mathrm{Ce}(2)-\mathrm{HBEA}$ was placed as first layer and $\mathrm{Pd}(0.3) \mathrm{Ce}(2)-\mathrm{HMOR}$ as second layer in the catalytic bed. The catalytic performance was significantly improved (higher $\mathrm{NO}_{\mathrm{x}}$ conversion into $\mathrm{N}_{2}$ and higher $\mathrm{CH}_{4}$ selectivity to $\mathrm{SCR}$ reaction), when compared to the catalytic performance of each catalyst individually, suggesting the existence of a synergic effect. This synergy is explained by the complementary roles that each catalyst play in HC-SCR mechanism.

Keywords: $\mathrm{NO}_{\mathrm{x}} \mathrm{HC}-\mathrm{SCR}$, methane, MOR, BEA, palladium, cerium, synergy. 


\section{Introduction}

The increasing concerns about air pollution control have recently resulted in the publication, by different countries, of legislation that establishesmore stringent maxima of allowed emission values for several pollutants (including nitrogen oxides, hydrocarbons and particulate matter), particularly in the road transportation sector (mobile sources)[1]. It is known that the importance of natural gas vehicles is increasing worldwide [2]. One possible after-treatment solution that simultaneously removes $\mathrm{NO}_{\mathrm{x}}$ and $\mathrm{HC}$ from the exhaust gases of these vehicles, working in lean-burn conditions, is the $\mathrm{NO}_{\mathrm{x}}$ selective catalytic reduction with hydrocarbons(HC-SCR) over zeolite-based catalysts containing metals[3-5].Despite several decades of studies, this technology still lacks some technological improvement in order to be successfully implemented as a commercial solution.

Pd-zeolites are known to be active for $\mathrm{NO}_{\mathrm{x}} \mathrm{SCR}$ using methane, under lean conditions, as a reductant[6-8]. The catalytic performance of these catalysts can be improved by considering bimetallic formulations, such as PdCo-zeolites[9, 10] and PdCe-zeolites[11, 12].Despite being active and selective catalysts, it has been reported in literature that PdCo-zeolites [13] suffer from deactivation over time, but the same seems not to happen with PdCe-zeolites, which activity has been reported to be constant over the time [14].Hence, the further understanding of the role of Ce in these catalysts might be important to move forward towards a commercial application of this type of aftertreatment system.

Few works can be found in literature, describing the combination of different catalysts in dual catalysts systems as a possible solution for HC-SCR. For instance, Chen, et al. have reported the existence of synergies between different zeolites (namely, Fe-MFI and 
Fe-FER) in the $\mathrm{NO}_{\mathrm{x}} \mathrm{SCR}$ with iso-butane [15]. Fe-FER presents lower activity $\mathrm{NO}_{\mathrm{x}}$ SCR because the small pores of FER structure become blocked by nitrogen-containing compounds formed dueto the interaction between the hydrocarbons and $\mathrm{NO}_{\mathrm{x}}$. However, $\mathrm{NO}_{2}$ is smaller enough to pass through the channels. On the other hand, Fe-MFI deactivates over time due to the formation of a deposit that blocks the sites responsible for the NO oxidation to $\mathrm{NO}_{2}$, which is considered to be a first key step in the HC-SCR mechanism [16]. By mixing Fe-FER with Fe-MFI, the $\mathrm{NO}_{2}$ formed in Fe-FER is able to interact with the active groups of the deposit on Fe-MFI and a resulting enhancement on catalytic performance is foreseen.

Holmgreen, et al., havealso studied the use of dual catalysts system for HC-SCR in lean-burn conditions, namely using methane as reductant [17]. They observed an enhancing effect on $\mathrm{NO}_{\mathrm{x}} \mathrm{SCR}$ performance of Pd-supported sulphated zirconia (reduction catalyst), when mixedwith an oxidation catalyst, such as Co impregnated on zirconia (with low activity for $\mathrm{NO}_{\mathrm{x}} \mathrm{SCR}$ but high activity for $\mathrm{NO}$ oxidation to $\mathrm{NO}_{2}$ ).

In this work, the catalytic performance of PdCe-zeolites (MOR and BEA) for $\mathrm{NO}_{\mathrm{x}} \mathrm{SCR}$ with methane is compared. The choice of these zeolites structures was based on the facts that (i) MOR is described in literature as azeolite structure that leads to active Pd and Pd-Ce catalysts for $\mathrm{NO}_{\mathrm{x}} \mathrm{CH}_{4}$-SCR $[12,13,18]$; (ii) BEA zeolite has been used in a catalyst that exhibited enhanced catalytic performance for $\mathrm{NO}_{\mathrm{x}} \mathrm{CH}_{4}-\mathrm{SCR}$ after being exposed to water [9], which is naturally present in realexhaust gases.Different characterisation techniques were used in order to identify the main differences in the metal species stabilised in the zeolite structures. A potential synergic effect on $\mathrm{NO}_{\mathrm{x}}$ SCR with methane due to the mixture of the different zeolite-based catalysts containing identicalPd and Ce metal loadings is reported for the first time. 


\section{Experimental}

\subsection{Catalysts preparation}

Catalysts were prepared from CBV21A zeolite $\left(\mathrm{NH}_{4} \mathrm{MOR}\right)$, with $\mathrm{Si} / \mathrm{Al}=10$ and CP814E zeolite $\left(\mathrm{NH}_{4} \mathrm{BEA}\right)$, with $\mathrm{Si} / \mathrm{Al}=12.5$, supplied by Zeolyst. In order to obtain $\operatorname{Pd}(0.3)$-HMOR and $\operatorname{Pd}(0.3)-H B E A, 0.3$ wt.\% of palladium was introduced by ionexchanging the starting zeolites with a solution with adequate concentration, prepared by dilution of a $\mathrm{Pd}\left(\mathrm{NH}_{3}\right)_{4}\left(\mathrm{NO}_{3}\right)_{2}$ aqueous solution (Aldrich, $99.99 \%$ purity, 10 wt.\%), for $24 \mathrm{~h}$, at room temperature. Afterwards, exchanged samples were recovered by centrifugation and dried in an oven at $90^{\circ} \mathrm{C}$, overnight. Pd-zeolites were then calcined under air-flow, at $500{ }^{\circ} \mathrm{C}$, for $1 \mathrm{~h}\left(1^{\circ} \mathrm{C} / \mathrm{min}\right)$. $\mathrm{Pd}(0.3) \mathrm{Ce}(2)-\mathrm{HMOR}$ and $\mathrm{Pd}(0.3) \mathrm{Ce}(2)-$

HBEA were obtained from $\operatorname{Pd}(0.3)$-HMOR and $\operatorname{Pd}(0.3)$-HBEA, respectively, by introducing 2 wt.\% of cerium by incipient wetness impregnation technique, using a solution with adequate concentration, prepared with $\mathrm{Ce}\left(\mathrm{NO}_{3}\right)_{3} \cdot 6 \mathrm{H}_{2} \mathrm{O}$ salt (Fluka, 99\% purity). Then, samples were dried in an oven at $90^{\circ} \mathrm{C}$, overnight, and finally calcined at $500^{\circ} \mathrm{C}$, for $8 \mathrm{~h}\left(5^{\circ} \mathrm{C} / \mathrm{min}\right)$.

\subsection{Catalysts characterisation}

Temperature programmed reduction under hydrogen $\left(\mathrm{H}_{2}\right.$-TPR) was performed by contacting a catalyst sample (ca. $100 \mathrm{mg}$ ) with a mixture of $\mathrm{H}_{2}(5$ vol.\% in Ar, 30 $\mathrm{mL} / \mathrm{min}$ ) and heating it until $900^{\circ} \mathrm{C}$ using a ramp of $7.5^{\circ} \mathrm{C} / \mathrm{min}$. Hydrogen consumption was measured with a thermal conductivity detector. Water was trapped in a dry icecooled trap. 
Diffuse reflectance spectra in the UV-Vis range (DRSUV-Vis) were collected on a Varian Cary 5000 UV-Vis-NIR spectrophotometer equipped with a Praying Mantisaccessory. Spectra were collected at room temperature, using calcined samples (range 200-800 $\mathrm{nm}$, scan rate $-600 \mathrm{~nm} / \mathrm{min}$, data interval - $1 \mathrm{~nm}$, SBW - $4 \mathrm{~nm}$ ). Reflectance spectra were converted into the Schuster-Kubelka-Munk (SKM) function, $\mathrm{F}(\mathrm{R})$, calculated at each wavelength using the expression:

$$
F(R)=\frac{(1-R)^{2}}{2 R}
$$

$\mathrm{R}$ is the ratio of the intensity of the light reflected by the sample to the one reflected by a standard. In order to minimise the effect of zeolite framework absorption, the standard considered was a parent HMOR and HBEA zeolite sample, obtained from $\mathrm{NH}_{4} \mathrm{MOR}$ and $\mathrm{NH}_{4} \mathrm{BEA}$ samples throughout the same calcination procedure described before, after cerium introduction in bimetallic samples.

Transmission electron microscopy (TEM) was performed on a JEOL JEM 2010microscope (LaB6 cannon) operating at $200 \mathrm{kV}$. Prior to TEM, samples were crushed and then dispersed with ethanol on a carbon-coated copper TEMgrid. Energydispersive X-ray spectroscopy (EDS) was also performed (probe PGT-Bruker).

$\mathrm{CO}$ adsorption followed by Fourier transform infraredspectroscopy was also performed in order to obtain further information regarding the physicochemical properties of the catalysts surface. Spectra were collected with a Nicolet 6700 FTIR spectrometer (400$4000 \mathrm{~cm}^{-1}, 128$ scans, $4 \mathrm{~cm}^{-1}$ resolution). Self-supporting wafers of catalyst ( $\mathrm{ca} .10$ $\mathrm{mg} / \mathrm{cm}^{2}$ ) were pre-treated by heating to $400{ }^{\circ} \mathrm{C}$ at $3{ }^{\circ} \mathrm{C} / \mathrm{min}$, then holding for $30 \mathrm{~min}$, inside a vacuum cell ( $\mathrm{P}<10^{-4} \mathrm{~Pa}$, equipped with $\mathrm{CaF}_{2}$ windows) attached to the vacuum line. After pre-treatment, wafers were reduced at $400{ }^{\circ} \mathrm{C}$, for $1 \mathrm{~h}$, under 100 torr of $\mathrm{H}_{2}$. After reduction, the cell was evacuated for $10 \mathrm{~min}$ to $\mathrm{P}<10^{-5}$ torr. The wafers were then 
cooled down to room temperature and a spectrum was collected prior to $\mathrm{CO}$ adsorption. Next, 5 torr of $\mathrm{CO}$ was introduced into the cell anda spectrum was obtained.The $\mathrm{CO}$ gas phase spectrum was collected. All spectra presented were obtained after subtracting CO gas phase and the activated sample (after reduction) contributions, and they were normalised at the same weight/surface wafer ratio.

\subsection{Catalytic tests}

Catalytic tests were performed in a tubular pyrex reactor using $190 \mathrm{mg}$ of catalyst (dry basis) corresponding to a GHSV of $40000 \mathrm{~h}^{-1}$. For the dual bed test, $95 \mathrm{mg}$ of $\operatorname{Pd}(0.3) \mathrm{Ce}(2)-\mathrm{HMOR}$ were first loaded to the reactor, and then $95 \mathrm{mg}$ of $\mathrm{Pd}(0.3) \mathrm{Ce}(2)-$ HBEA were carefully loaded, in order to obtain two separate layers, so that the inlet gas mixture would contact BEA catalyst first. Before the reaction, a pre-treatment was performed consisting in heating the catalyst under argon flow $(15 \mathrm{~L} / \mathrm{h})$, from room temperature to $500{ }^{\circ} \mathrm{C}\left(5^{\circ} \mathrm{C} / \mathrm{min}\right)$ and keeping this temperature for $1 \mathrm{~h}$, in order to clean the catalysts' surface. Then, the reactor was cooled to $300{ }^{\circ} \mathrm{C}$ still under argon flow. Meanwhile, the reaction mixture was stabilised in a reactor by-pass, using two four-way valves. Once stable, the reaction mixture was fed to the reactor. When the steady state was reached, the temperature was raised $50{ }^{\circ} \mathrm{C}$. This procedure was repeated until 500 ${ }^{\circ} \mathrm{C}$.

$\mathrm{NO}_{\mathrm{x}} \mathrm{SCR}$ tests were performed using a mixture of 1000 ppm NO, 1000 ppm $\mathrm{CH}_{4}, 7$ vol. $\% \mathrm{O}_{2}$ and 2 vol. $\% \mathrm{H}_{2} \mathrm{O}$ in flowing argon (total flow rate of $250 \mathrm{~mL} / \mathrm{min}$, GHSV =

$40000 \mathrm{~h}^{-1}$ ). NO oxidation to $\mathrm{NO}_{2}$ tests were performed using a mixture of $1000 \mathrm{ppm}$ NO and 7 vol. $\% \mathrm{O}_{2}$ in flowing argon (total flow rate of $250 \mathrm{~mL} / \mathrm{min}$, GHSV $=40000 \mathrm{~h}^{-1}$ ). 
The reactor's outflow was continuously analysed. $\mathrm{NO}$ and $\mathrm{NO}_{2}$ concentrations were detected by a Thermo $42 \mathrm{C}$ chemiluminescence analyser. $\mathrm{CO}, \mathrm{CO}_{2}$ and $\mathrm{N}_{2} \mathrm{O}$ concentrations were detected by an ABB EL 3020 infrared analyser. A Pfeiffer Vacuum GSD 301 mass spectrometer was also used to follow the reaction, namely theconstant amount of water introduced in the inlet stream $(\mathrm{m} / \mathrm{z}=17$ and 18$)$.

For each temperature $T, \mathrm{NO}_{\mathrm{x}}$ conversion into $\mathrm{N}_{2}$ was obtained using equation (2), $\mathrm{CH}_{4}$ conversion into $\mathrm{CO}_{2}$ was obtained using equation (3) and selectivity of methane to SCR reaction was obtained using equation (4).

$$
\begin{gathered}
x_{N O_{x} \text { to } N_{2}, T}(\%)=\left(1-\frac{n_{N O, T}+n_{N O_{2}, T}+2 n_{N_{2} O, T}}{n_{N O, 0}+n_{N O_{2}, 0}}\right) \times 100 \% \\
x_{C H_{4} \text { into } C_{2}, T}(\%)=\frac{n_{C O_{2}, T}}{n_{C H_{4}, 0}} \times 100 \% \\
S_{C H_{4} \text { to SCR }, T}(\%)=\frac{n_{C H_{4} \text { for } S C R, T}}{n_{C H_{4} \text { converted }, T}}=\frac{n_{N O, 0}+n_{N O_{2}, 0}-\left(n_{N O, T}+n_{N O_{2}, T}+2 n_{N_{2} O, T}\right)}{n_{C H_{4}, 0}-\left(n_{C O_{2}, T}+n_{C O, T}\right)} \times 100 \%
\end{gathered}
$$

0 represents the initial condition (by-pass mixture) before starting the reaction. 


\section{Results and Discussion}

\subsection{Temperature programmed reduction under hydrogen $\left(\mathrm{H}_{2}\right.$-TPR)}

Figure 1 shows the $\mathrm{H}_{2}$-TPR profiles of the studied catalysts. The $\mathrm{H}_{2}$-TPR profiles of both HMOR and HBEA catalysts, obtained by applying the same calcination procedure as the one described in the catalyst preparation section for bimetallic catalysts (after cerium introduction) did not exhibit any reduction process. For bothPd(0.3)-HMOR and $\mathrm{Pd}(0.3) \mathrm{Ce}(2)-\mathrm{HMOR}$, it is possible to observe the existence of a reduction peak between $80-200{ }^{\circ} \mathrm{C}$, which is assigned to the reduction of $\mathrm{Pd}^{2+}$ in exchange positions to $\mathrm{Pd}^{0}[19-21]$.The integration of this peak results in a $\mathrm{H}_{2} / \mathrm{Pd}$ ratio of $c a$. 1.1 for $\mathrm{Pd}(0.3)-$ HMOR, which is consistent with the stabilisation of all the palladium as $\mathrm{Pd}^{2+}$ in exchange position in literature[21]. For $\mathrm{Pd}(0.3) \mathrm{Ce}(2)-\mathrm{HMOR}$, the integration of this peak results in a $\mathrm{H}_{2} / \mathrm{Pd}$ ratio of $c a$. 1.8 , which is significantly higher than the unity. In fact, the reduction of surface $\mathrm{Ce}^{4+}$ species to $\mathrm{Ce}^{3+}$ is known to take place in this range of temperatures [22], which explains this result.

For $\mathrm{Pd}(0.3)$-HBEA, no reduction peak is observed in the entire range of temperatures. It has been reported in literature that palladium is stabilised in BEA zeolite as $\mathrm{PdO}$, which reduction is likely to occur between -20 to $25^{\circ} \mathrm{C}$ [23], explaining the absence of reduction peaks in the $\mathrm{H}_{2}$-TPR profile of $\mathrm{Pd}(0.3)$-HBEA. However, when cerium is added to $\mathrm{Pd}(0.3)$-HBEA, two reduction peaks are visible between $60-180{ }^{\circ} \mathrm{C}$ (see $\mathrm{H}_{2}$ TPR profile of $\operatorname{Pd}(0.3) \mathrm{Ce}(2)-\mathrm{HBEA})$. The integration of first reduction peak, $60-120^{\circ} \mathrm{C}$, results in a $\mathrm{H}_{2} / \mathrm{Pd}$ ratio of 0.4 . One can speculate that the presence of Ce may promote the stabilisation of part of the palladium as $\mathrm{Pd}^{2+}$ ions in exchange position or, eventually, contributes for a more difficult reduction (i. e.at higher temperature) of part of the $\mathrm{PdO}$. The second reduction peak, $120-180{ }^{\circ} \mathrm{C}$, is ascribed to the reduction of 
surface $\mathrm{Ce}^{4+}$ species [22], similar to what happens for $\mathrm{Pd}(0.3) \mathrm{Ce}(2)-\mathrm{HMOR}$ (in order to provide a term of comparison between both bimetallic catalysts, the $\mathrm{H}_{2} / \mathrm{Pd}$ ratio corresponding to the reduction peak of $\mathrm{Ce}^{4+}$ species in $\mathrm{Pd}(0.3) \mathrm{Ce}(2)-\mathrm{HBEA}$ is 0.17 , significantly lower than in $\mathrm{Pd}(0.3) \mathrm{Ce}(2)-\mathrm{HMOR}=1.8-1.1=0.9)$

Finally, for both bimetallic catalysts, a broad reduction peak can be observed between $300-550{ }^{\circ} \mathrm{C}$, which can be attributed to $\mathrm{CeO}_{2}$ species. The reduction of the most easily reducible surface capping oxygen of $\mathrm{CeO}_{2}$ usually occurs at slightly higher temperatures $\left(\right.$ ca.500 $\left.{ }^{\circ} \mathrm{C}\right)[22]$. However, due to interaction with other metal species, namely palladium, it has been reported a shift to lower temperatures[22, 24], which can explain the fact that this reduction process begins at $300{ }^{\circ} \mathrm{C}$. The integration of these peaks leads to a $\mathrm{H}_{2} / \mathrm{Pd}$ ratio of 0.13 for $\mathrm{Pd}(0.3) \mathrm{Ce}(2)$-HMOR and 0.31 for $\mathrm{Pd}(0.3) \mathrm{Ce}(2)-\mathrm{HBEA}$.

\subsection{Diffuse reflectance UV-Visspectroscopy (DRSUV-Vis)}

Figure2A and B illustrate the DRSUV-Vis spectra for both MOR and BEA catalyst series, respectively.For $\mathrm{Pd}(0.3)-\mathrm{HMOR}$, a single band is observed at approximately 400 $\mathrm{nm}$, which is attributed to $\mathrm{d}-\mathrm{d}$ transitions of $\mathrm{Pd}^{2+}$ ions [25]. This band appears slightly blue-shifted $(385 \mathrm{~nm})$ in $\operatorname{Pd}(0.3) \mathrm{Ce}(2)-\mathrm{HMOR}$ spectrum, which might be an effect of the presence of cerium. For the bimetallic MOR based catalyst, two additional bands can be clearly identified. The band at $260 \mathrm{~nm}$ is ascribed to the transition $4 \mathrm{f}-5 \mathrm{~d}$ of $\mathrm{Ce}^{3+}$ species[26] and the band at $290 \mathrm{~nm}$ is characteristic of the charge transfer from $\mathrm{O}^{2-}$ to $\mathrm{Ce}^{4+}$ in $\mathrm{CeO}_{2}$ clusters [26].

$\operatorname{Pd}(0.3)$-HBEA exhibits a broad band at $335 \mathrm{~nm}$, which is ascribed to charge transfer $\mathrm{Pd} \rightarrow \mathrm{O}[27]$. For $\mathrm{Pd}(0.3) \mathrm{Ce}(2)-\mathrm{HBEA}$, two additional bands at 260 and $290 \mathrm{~nm}$ appear overlapped with the previous mentioned band. These two bands are the same 
onesobserved for $\mathrm{Pd}(0.3) \mathrm{Ce}(2)-\mathrm{HMOR}$ and can be ascribed to $\mathrm{Ce}^{3+}$ and $\mathrm{Ce}^{4+}$ species, respectively.

\subsection{Transmission electron microscopy (TEM)}

TEM images (Figure 3) allow to evidence significant differences in the Ce and $\mathrm{Pd}$ species that are stabilised in the studied zeolites (MOR and BEA).

No metal particles were observed in all TEM images collectedforPd(0.3)-HMOR sample (Figure 3A). Moreover, the several energy-dispersive X-ray spectroscopy (EDS) analyses performed did not detect the presence of palladium. However, $\mathrm{H}_{2}-\mathrm{TPR}$ and DRS UV-Vis confirmed the existence of Pd species, which supports the idea that palladium is well dispersed in the catalyst as $\mathrm{Pd}^{2+}$ in exchange positions, which cannot be detected by TEM.

Small metal particles $\left(\bar{d}_{p}=5 \mathrm{~nm}\right)$ can be observed in the external surface of the zeolite particles of $\mathrm{Pd}(0.3) \mathrm{Ce}(2)-\mathrm{HMOR}$ (Figure 3B). EDS analyses identified cerium as the element present in these particles. Moreover, high resolution TEM (HRTEM) allowed the quantification of the distance between lattice planes in 3.1 and $2.7 \AA$,typical from $\mathrm{CeO}_{2}$ (ICDD 00-034-0394). The fact that palladium was not observed in TEM images, or detected by EDS, suggests that even after the addition of cerium to $\operatorname{Pd}(0.3)$-HMOR, palladium remains stabilised as dispersed $\mathrm{Pd}^{2+}$ ions in exchange position.

Contrarily to Pd(0.3)-HMOR, TEM images of Pd(0.3)-HBEA reveal the existence of metal clusters in the external surface of the BEA zeolite particles (Figure 3C). EDS analyses confirmed that these are, indeed, palladium clusters and HRTEMallowed the quantification of the distance between lattice planes in $2.6 \AA$, typical from PdO (ICDD 
00-041-1107).PdOclusters were also identified in $\mathrm{Pd}(0.3) \mathrm{Ce}(2)$-HBEA (Figure 3D). Moreover, $\mathrm{CeO}_{2}$ clusters were also identified in this catalyst. It is worthy to highlight that these cerium clusters are significantly larger than the $\mathrm{CeO}_{2}$ particles detected in $\operatorname{Pd}(0.3) \mathrm{Ce}(2)-\mathrm{HMOR}$.

Further results of the catalysts obtained by TEM can be found in the supporting data.

\subsection{CO adsorption followed by FTIR spectroscopy}

Figure 4 shows the FTIR spectra of the catalysts studied in this work, following adsorption of CO. For Pd(0.3)-HMOR, an intense band is observed at $2220 \mathrm{~cm}^{-1}$. According to Hadjiivanov and Vayssilov[28], IR bands in 2215-2110 $\mathrm{cm}^{-1}$ spectral range have been attributed to linear $\mathrm{Pd}^{\mathrm{n}+}-\mathrm{CO}$ complexes. Although the $2220 \mathrm{~cm}^{-1}$ band appears slightly blue-shifted from the $\mathrm{Pd}^{\mathrm{n}+}-\mathrm{CO}$ spectral range, one could be led to ascribe this band to such species. However, as all catalyst were reduced prior to $\mathrm{CO}$ adsorption, this band is assigned to $\mathrm{Al}^{3+}-\mathrm{CO}$ complexes [28-30], which was also confirmed by the $\mathrm{CO}$ adsorption experiments on Pd free HMOR.The formation of such complexes is likely to occurin the presence of $\mathrm{CO}$ interacting with theextra-aluminium species responsible for Lewis acidity, even at room temperature[18, 21]. A second band observed at $2198 \mathrm{~cm}^{-}$ ${ }^{1}$ can be also ascribed to Lewis acid sites (LAS), which is in agreement with the results obtained by Reifsnyder, et al.[21].A low intensity band at $2169 \mathrm{~cm}^{-1}$ can be ascribed to Brønsted acid sites (BAS) $[18,21]$, or to residual Pd cationic species, for instance $\mathrm{Pd}^{2+}[28]$. A weak band $2137 \mathrm{~cm}^{-1}$ also appears in the spectral range of $\mathrm{Pd}^{\mathrm{n}+}$ carbonyls. It can beassignedPd ${ }^{+}-\mathrm{CO}$ orPd $^{\delta+}-\mathrm{CO}$ complexes [21], which indicate the presence of cationic Pd species or small positively charged Pd clusters in the vicinity of BAS even after the sample reduction at $400{ }^{\circ} \mathrm{C}$. Bands below $2100 \mathrm{~cm}^{-1}$ are characteristic of $\mathrm{CO}$ 
interactions with metallic palladium species[28]. The band at $2099 \mathrm{~cm}^{-1}$ is attributed to linear $\mathrm{Pd}^{0}-\mathrm{CO}$ complexes, whereas the bands at 1962 and $1898 \mathrm{~cm}^{-1}$ are ascribed to bridging $\mathrm{CO}$ on $\mathrm{Pd}^{0}$ clusters (two-fold and three-fold coordination, respectively[31]).

For $\mathrm{Pd}(0.3) \mathrm{Ce}(2)-\mathrm{HMOR}$, similar bands are observed in the spectrum. However, two new and intense bands appear at $2188 \mathrm{~cm}^{-1}$ and $2355 \mathrm{~cm}^{-1}$. According to Hadjiivanov and Vayssilov, carbonyls formed with cerium ions have characteristic bands in the spectral region of $2190-2110 \mathrm{~cm}^{-1}[28]$. One can ascribed the band at $2188 \mathrm{~cm}^{-1}$ to $\mathrm{Ce}^{\mathrm{n}+}-$ CO complexes $\left(\mathrm{Ce}^{3+}\right.$ or $\left.\mathrm{Ce}^{4+}\right)$. Indeed, in the DRS UV-vis spectrum of $\mathrm{Pd}(0.3) \mathrm{Ce}(2)$ HMOR (Figure 2a), absorption bandscharacteristic of both species have been observed. The band $2355 \mathrm{~cm}^{-1}$ is attributed to linear $\mathrm{CO}_{2}[32]$, which is likely to result from the oxidation of $\mathrm{CO}$ to $\mathrm{CO}_{2}$ on the cerium sites. A significantly less intense band, at 2290 $\mathrm{cm}^{-1}$, is also observed in the spectrum and is likewise attributed to $\mathrm{CO}_{2}$ complexes. Though the bands at 2141 and $2123 \mathrm{~cm}^{-1}$ are within the spectral range of $\mathrm{Ce}^{\mathrm{n}+}-\mathrm{CO}$ complexes, these bands might be also due toPd ${ }^{\mathrm{n}+}-\mathrm{CO}$ complexes. In fact, it is likely that the presence of $\mathrm{CeO}_{2}$ (also detected by $\mathrm{H}_{2}$-TPR and TEM - Figure 1 and 3B, respectively) attenuates the reduction of Pd species or promotes its re-oxidation. At the same time, some of the palladium is presented in metallic form, which is evidenced by the characteristic bands at 2101, 1959 and $1894 \mathrm{~cm}^{-1}$.

For the reduced Pd(0.3)-HBEA catalyst, two bands at 2226 and $2188 \mathrm{~cm}^{-1}$, can be observed in the CO spectrum, which are attributed to LAS of BEA zeolite [33, 34], similarly to what was observed for $\operatorname{Pd}(0.3)$-HMOR. In addition, for $\operatorname{Pd}(0.3)$-HBEA, the bands attributed toPd ${ }^{\mathrm{n}+}-\mathrm{CO}$ complexes are not observed. For metallic Pd species, typical bands of linear $\mathrm{Pd}^{0}-\mathrm{CO}$ complexes (around $2100 \mathrm{~cm}^{-1}$ ) are not visible, and only a band characteristic of bridging $\mathrm{CO}$ in $\mathrm{Pd}$ clusters is observed at $1894 \mathrm{~cm}^{-1}$. This result supports the idea that, conversely to $\mathrm{Pd}(0.3)-\mathrm{HMOR}, \mathrm{Pd}$ is lesswell dispersed in the 
BEA structure, resulting in the formation of larger $\mathrm{Pd}^{0}$ species. This in agreement with the TEM/EDSdata, which confirms the presence of PdO clusters (before reduction). In $\operatorname{Pd}(0.3)$-HBEA spectrum, a low intensity band at $2363 \mathrm{~cm}^{-1}$ is observed, which could be ascribed to $\mathrm{CO}_{2}$ complexes. One can speculate that part of $\mathrm{Pd}^{0}$ clusters might have been re-oxidised leading to the formation $\mathrm{PdO}$, which would be responsible for $\mathrm{CO}$ oxidation to $\mathrm{CO}_{2}$.

In the spectrum of $\mathrm{Pd}(0.3) \mathrm{Ce}(2)-\mathrm{HBEA}$ the bands at 2226 and $2188 \mathrm{~cm}^{-1}$ are more intense than those previously observed in $\operatorname{Pd}(0.3)$-HBEA. This could be due to a higher number of LAS in this catalyst after the introduction of cerium. Alternatively, the increase in intensity of the $2188 \mathrm{~cm}^{-1}$ band could be related to the presence of $\mathrm{Ce}^{\mathrm{n}+}$ or $\mathrm{Pd}^{\mathrm{n}+}$ species. In fact, an additional band is observed at $2127 \mathrm{~cm}^{-1}$ which could be attributed to $\mathrm{Pd}^{+}-\mathrm{CO}$ complexes. Moreover, unlike for $\mathrm{Pd}(0.3)$-HBEA, bands at 2107 and $1972 \mathrm{~cm}^{-1}$ are observed in $\operatorname{Pd}(0.3) \mathrm{Ce}(2)$-HBEA, which suggests the existence of an higher relative amount of metallic palladium in smaller clusters allowing linear and two-fold bridging coordination. These results indicate that the presence of cerium oxide may promote the re-dispersion of Pd in BEA structure. Finally, the band at $2358 \mathrm{~cm}^{-1}$ is assigned to linear $\mathrm{CO}_{2}$, which is in agreement with the observation for $\operatorname{Pd}(0.3) \mathrm{Ce}(2)$ HMOR.

\subsection{Catalytic tests}

\subsection{1. $\mathrm{NO}$ oxidation to $\mathrm{NO}_{2}$}

According to literature, $\mathrm{NO}$ oxidation to $\mathrm{NO}_{2}$ is a first key step in the $\mathrm{NO}_{\mathrm{x}} \mathrm{SCR}$ mechanism when using hydrocarbons as reductant (HC-SCR)[16].Hence, the catalytic performance for this reaction was assessed (Figure 5). Pd(0.3)-HMOR shows a poor 
activity for $\mathrm{NO}$ oxidation and even $\mathrm{Pd}(0.3) \mathrm{Ce}(2)$-HMORexhibits a modest activity for NO oxidation. However, $\operatorname{Pd}(0.3)$-HBEA shows to be considerably active for this reaction. Moreover, $\mathrm{Pd}(0.3) \mathrm{Ce}(2)$-HBEA shows to be very effective in oxidising NO to $\mathrm{NO}_{2}$, with the conversion values very close to the thermodynamic equilibrium in practically the entire range of tested temperatures.

Cerium is well known to catalyse NO oxidation [11].In fact, FTIR-CO spectra of both $\operatorname{Pd}(0.3) \mathrm{Ce}(2)-\mathrm{HMOR}$ and $\mathrm{Pd}(0.3) \mathrm{Ce}(2)$-HBEA exhibit very intense bands attributed to the formation of $\mathrm{CO}_{2}$ complexes that resulted from $\mathrm{CO}$ oxidation (Figure 4), oppositely to what was observed for monometallic catalysts. When looking to each catalyst series separately (MOR and BEA), the presence of cerium in the bimetallic formulation explains the higher $\mathrm{NO}$ oxidation values of these catalysts when compared to their equivalent monometallic catalysts.

It is interesting to note thatPd(0.3)-HMOR and $\mathrm{Pd}(0.3)$-HBEA exhibit very different catalytic performances for this reaction. The poor catalytic activity of $\operatorname{Pd}(0.3)$-HMOR can be attributed to the fact that practically all palladium is stabilised as $\mathrm{Pd}^{2+}$ ions instead of $\mathrm{PdO}$, which is a species known to promote oxidation reactions $\left(\right.$ e.g. $\mathrm{CH}_{4}$ oxidation[35]).

\subsection{2. $\underline{\mathrm{NO}_{x}} \underline{\underline{\mathrm{SCR}} \text { with } \mathrm{CH}_{4}}$}

The results for $\mathrm{NO}_{\mathrm{x}} \mathrm{SCR}$ tests are illustrated in Figure $6\left(\mathrm{~N}_{2} \mathrm{O}\right.$ and $\mathrm{CO}$ formation are negligible).It is possible to observed that MOR based catalysts are more active for $\mathrm{NO}_{\mathrm{x}}$ SCR reaction than BEA based catalysts. This result was quite unexpected considering the very high activity for NO oxidation, observed for BEA based catalysts. It must be highlighted that even non-selective total oxidation of methane was quite poor.Active Pd-zeolites are known to lose activity when, under certain conditions, Pd tends to 
agglomerate into large $\mathrm{PdO}$ clusters, $i$. e., due to loss of $\mathrm{Pd}$ dispersion[8, 12]. The fact that $\mathrm{Pd}$ is stabilised as $\mathrm{Pd}^{2+}$ in exchange positions in both $\mathrm{Pd}(0.3)$-HMORand $\operatorname{Pd}(0.3) \mathrm{Ce}(2)-\mathrm{HMOR}$ and as PdOclusters in $\mathrm{Pd}(0.3)$-HBEA and $\mathrm{Pd}(0.3) \mathrm{Ce}(2)-$ HBEA,might explain the differences on the catalytic behaviour. Also, the fact thatthis latter catalyst presents a notable performance for NO oxidation but very poor activity for $\mathrm{NO}_{\mathrm{x}} \mathrm{SCR}$, indicates that the presence of $\mathrm{Pd}^{2+}$ ions in exchange positions is crucial for this reaction, which has already been reported in literature [8].

It is known that the addition of $\mathrm{Ce}$ to $\mathrm{Pd}$-zeolite catalysts enhances the catalytic performance[12]. In fact, the $\mathrm{NO}_{\mathrm{x}}$ conversion values are higher for $\operatorname{Pd}(0.3) \mathrm{Ce}(2)$ HMOR when compared to $\mathrm{Pd}(0.3)$-HMOR. This enhancing effect is attributed to different roles of Ce: (i) the promotion of $\mathrm{NO}$ oxidation to $\mathrm{NO}_{2}[11]$; (ii) the stabilisation of $\mathrm{Pd}^{2+}$ ions in the most active exchange positions $[11,12]$; (iii) inhibition of the formation of $\mathrm{PdO}$ particles [12]. These latter two effects can be justified by an interaction between $\mathrm{Pd}$ and Ce species. $\mathrm{H}_{2}$-TPR profiles evidence that this interaction in $\mathrm{Pd}(0.3) \mathrm{Ce}(2)-\mathrm{HBEA}$ is more extensive than in $\mathrm{Pd}(0.3) \mathrm{Ce}(2)-\mathrm{HMOR}$ (the $\mathrm{H}_{2} / \mathrm{Ce}$ ratio obtained by the quantification of the reduction peak between $300-550^{\circ} \mathrm{C}$ is higher for $\operatorname{Pd}(0.3) \mathrm{Ce}(2)-\mathrm{HBEA})$. However, by crossing this information with the catalytic test results, it seems that the pertinent interaction between $\mathrm{Ce}$ and $\mathrm{Pd}$ from the $\mathrm{NO}_{\mathrm{x}} \mathrm{SCR}$ point of viewneeds, necessarily,to involve $\mathrm{Pd}^{2+}$ ions (instead of $\mathrm{PdO}$ ).

In general, one can say that the $\mathrm{NO}_{\mathrm{x}}$ conversion values obtained for the catalytic tests are not particularly high, especially when comparing with similar systems described in literature (i.e.PdCe-based systems, namely considering MOR as support). However, it should be highlighted that the catalytic test conditions considered in this this work are significantly less favourable when compared with other studies (Table 1). 
For instance, Pieterse, et al. [14] reported a $\mathrm{NO}_{\mathrm{x}}$ conversion of $c a .60 \%$, at $375^{\circ} \mathrm{C}$, with Ce-Pd-MOR (0.4 wt.\% Pd and 2-4 wt.\% Ce). However, the catalytic tests were performed with a feed of $500 \mathrm{ppm} \mathrm{NO}, 2500 \mathrm{ppm} \mathrm{CH}_{4}, 5$ wt.\% $\mathrm{O}_{2}$ and 5 vol.\% $\mathrm{H}_{2} \mathrm{O}$, i.e., using $\left[\mathrm{CH}_{4}\right] /[\mathrm{NO}]$ ratio in the inlet feed of 5 . The authors obtained even higher $\mathrm{NO}_{\mathrm{x}}$ conversions, $\mathrm{ca} .80 \%$ and $100 \%$ using inlet feeds with $\left[\mathrm{CH}_{4}\right] /[\mathrm{NO}]$ ratio of 7 and 19 , respectively. In this work, the $\left[\mathrm{CH}_{4}\right] /[\mathrm{NO}]$ ratio considered was 1 , which represents significantly less reductant. Moreover, the GHSV value considered in the previous mention study was $17000 \mathrm{~h}^{-1}$, which is less than half of the value considered in this study $\left(40000 \mathrm{~h}^{-1}\right)$.

Also, Costilla, et al. [12] reported a $\mathrm{NO}_{\mathrm{x}}$ conversion of $c a .65 \%$, at $500{ }^{\circ} \mathrm{C}$, with $\mathrm{Ce}-$ Pd/H-MOR (0.2 wt.\% Pd and 2 wt.\% Ce). In this case, the authors considered a feed of 1010 ppm NO, $3300 \mathrm{ppm} \mathrm{CH}_{4}, 4.1$ vol.\% and 5 vol.\% $\mathrm{H}_{2} \mathrm{O}$., consisting in a $\left[\mathrm{CH}_{4}\right] /[\mathrm{NO}]$ $>3$, and a GHSV $=33000 \mathrm{~h}^{-1}$. Once again, this consists in a favourable situation compared to one considered in this work.

Different studies involving other catalytic systems have been conducted considering similar feed mixtures. For instance, Gutierrez and Lombardo [36] reported a $\mathrm{NO}_{\mathrm{x}}$ conversion of $c a .40 \%$, at $500{ }^{\circ} \mathrm{C}$, with CoLa-HMOR catalysts (1.7 wt.\% Co and 1.2 wt.\% La), considering a feed of 1000 ppm NO, 1000 ppm $\mathrm{CH}_{4}, 2$ vol\%. $\mathrm{O}_{2}$ and 10 vol. $\% \mathrm{H}_{2} \mathrm{O}$. Notwithstanding, the GHSV considered was $7500 \mathrm{~h}^{-1}$, i.e., five times lower that the one consider in the present work.Gutierrez, et al.[37] conducted a catalytic test with PtCo-MOR (0.39 wt.\% Pt and 2.87 wt.\% Co) with a feed containing 1000 ppm NO, 1000 ppm $\mathrm{CH}_{4}, 2$ vol\%. $\mathrm{O}_{2}$ and 2 vol. $\% \mathrm{H}_{2} \mathrm{O}$, where they observed a $\mathrm{NO}_{\mathrm{x}}$ conversion of $36 \%$, at $500{ }^{\circ} \mathrm{C}$, considering a GHSV $=30000 \mathrm{~h}^{-1}$. The conversion value is slightly higher the ones obtained in this work, but the GHSV is also lower. 
Due to the complementary catalytic performances of both bimetallic catalysts $(\mathrm{Pd}(0.3) \mathrm{Ce}(2)-\mathrm{HMOR}$ shows poor $\mathrm{NO}$ oxidation activity and is mildly active for $\mathrm{NO}_{\mathrm{x}} \mathrm{SCR}$, whereas $\mathrm{Pd}(0.3) \mathrm{Ce}(2)-\mathrm{HBEA}$ exhibits high $\mathrm{NO}$ oxidation activity but is inactive for $\mathrm{NO}_{\mathrm{x}} \mathrm{SCR}$ ), a test considering a dual bed of both catalysts was performed to assess theeventual existence of synergies between them. If no synergy took place, one would expect that the conversion values forsuch test would be lowerthan the ones obtained for $\mathrm{Pd}(0.3) \mathrm{Ce}(2)-\mathrm{HMOR}$ due to a dilution effect of $\mathrm{Pd}(0.3) \mathrm{Ce}(2)-\mathrm{HMOR}$ by the inactive $\mathrm{Pd}(0.3) \mathrm{Ce}(2)$-HBEA on the catalytic bed (only $95 \mathrm{mg}$ against $190 \mathrm{mg}$ ). However, results show that the $\mathrm{NO}_{\mathrm{x}}$ conversion achieved by dual bed is higher than $\mathrm{Pd}(0.3) \mathrm{Ce}(2)-\mathrm{HMOR}$ and, also, $\mathrm{CH}_{4}$ conversion to $\mathrm{CO}_{2}$ is lower.

Infact, when analysing the values of selectivity of $\mathrm{CH}_{4}$ to $\mathrm{SCR}$ reaction for both dual bed and $\mathrm{Pd}(0.3) \mathrm{Ce}(2)-\mathrm{HMOR}$ catalysts (Figure 7), it is possible to observe that these values are higher in the case of dual bed catalyst. This means that, with this configuration, more $\mathrm{CH}_{4}$ is being effectively used as a reductant, instead of being directly oxidised to $\mathrm{CO}_{2}$ (combustion). This fact evidences a clear improvement in the catalytic performance.

According to the $\mathrm{NO}_{\mathrm{x}} \mathrm{HC}-\mathrm{SCR}$ mechanism proposed Djéga-Mariadassou and coworkers, the $\mathrm{NO}_{\mathrm{x}} \mathrm{SCR}$ reaction passes by three different reactions, each one corresponding to a cycle or function $[16,38]$, which are illustrated in Figure 8 . The first cycle $(\mathrm{F} 1)$ consist in the oxidation of $\mathrm{NO}$ to $\mathrm{NO}_{2}$. The $\mathrm{NO}_{2}$ will then partially oxidise the hydrocarbons to $\mathrm{C}_{\mathrm{x}} \mathrm{H}_{\mathrm{y}} \mathrm{O}_{\mathrm{z}}$ intermediary species (second cycle - F2) which are, indeed, the actual reductant responsible for regenerating the active sites involved in the direct decomposition of $\mathrm{NO}$ to $\mathrm{N}_{2}$ (third cycle - F3). 
The interpretation of the results suggests that a low performance of $\operatorname{Pd}(0.3) \operatorname{Ce}(2)$ HMOR for NO oxidation is limiting, up to some extent, its $\mathrm{NO}_{\mathrm{x}} \mathrm{SCR}$ performance, in particular, the catalytic function F1 of the 3-function HC-SCR mechanism proposed in literature[16, 38].

In the dual bed configuration, where the inlet gas mixture first contacts with $\operatorname{Pd}(0.3) \mathrm{Ce}(2)-\mathrm{HBEA}$, a high amount of $\mathrm{NO}_{2}$ is expected to be formed (see Figure 4). Then, when it reaches $\mathrm{Pd}(0.3) \mathrm{Ce}(2)-\mathrm{HMOR}$, it is likely that products resulting from the interaction of $\mathrm{NO}_{2}$ and $\mathrm{CH}_{4}$ can be produced ( $\mathrm{R}-\mathrm{NO}_{\mathrm{x}}$ species) and, subsequently, decomposed in partial oxidised hydrocarbons $\left(\mathrm{C}_{\mathrm{x}} \mathrm{H}_{\mathrm{y}} \mathrm{O}_{\mathrm{z}}\right)$ and $\mathrm{NO}(\mathrm{F} 2$ of the mechanism). These $\mathrm{C}_{\mathrm{x}} \mathrm{H}_{\mathrm{y}} \mathrm{O}_{\mathrm{z}}$ species have been identified as intermediate products, resulting from the $\mathrm{NO}_{2}-\mathrm{CH}_{4}$ interaction [38] and are believed to be required to regenerate the catalytic sites responsible for the direct decomposition of $\mathrm{NO}$ into $\mathrm{N}_{2}$ (function $\mathrm{F} 3$ of the mechanism). 


\section{Conclusions}

The use of different zeolites (BEA and MOR) in the preparation of bimetallic catalysts, containing similar amounts of metal, by addition of cerium to Pd-based catalyst resulted in two catalysts with completely different catalytic performances.Pd( 0.3$) \mathrm{Ce}(2)$ - $\mathrm{HBEA}$ has shown to be very effective in oxidising $\mathrm{NO}$ to $\mathrm{NO}_{2}$ and significantly better than $\mathrm{Pd}(0.3) \mathrm{Ce}(2)-\mathrm{HMOR}$. This reaction is considered to be a first key step on the $\mathrm{NO}_{\mathrm{x}} \mathrm{SCR}$ mechanism using hydrocarbons (HC-SCR). However,Pd(0.3)Ce(2)-HMOR revealed to be active for $\mathrm{NO}_{x} \mathrm{SCR}$ with $\mathrm{CH}_{4}$, whereas $\mathrm{Pd}(0.3) \mathrm{Ce}(2)$-HBEA exhibited a poor catalytic performance in the conditions considered in this study.

A combination of different characterisation techniques allowed to identify important differences in the metal species present in both MOR and BEA catalysts.

In $\mathrm{Pd}(0.3)-\mathrm{HMOR}$, palladium is stabilised as $\mathrm{Pd}^{2+}$ in exchange positions, whereas it is stabilised as $\mathrm{PdO}$ particles in $\mathrm{Pd}(0.3)$-HBEA. In $\mathrm{Pd}(0.3) \mathrm{Ce}(2)-\mathrm{HMOR}$, cerium is presented as small $\mathrm{CeO}_{2}$ particles, whereas in $\mathrm{Pd}(0.3) \mathrm{Ce}(2)-\mathrm{HBEA}$, cerium is stabilised in large clusters of $\mathrm{CeO}_{2}$ distributed in the external surface of the zeolite, which are likely to be responsible for the NO oxidation performance. The palladium species are kept as $\mathrm{Pd}^{2+}$ in exchange positions in $\mathrm{Pd}(0.3) \mathrm{Ce}(2)-\mathrm{HMOR}$ and PdOclusters in $\operatorname{Pd}(0.3) \mathrm{Ce}(2)-\mathrm{HBEA}$. The lack of $\mathrm{Pd}^{2+}$ explains the low activity of BEA catalysts for $\mathrm{NO}_{\mathrm{x}} \mathrm{SCR}$ reaction.

A synergic effect was observed in the $\mathrm{NO}_{\mathrm{x}} \mathrm{SCR}$ performance when both bimetallic catalysts were tested in dual bed configuration. This synergy can be explained by the complementary catalytic behaviour of both catalysts in performing the different function of HC-SCR mechanism. 


\section{Acknowledgements}

The authors acknowledge Fundação para a Ciência e a Tecnologia (FCT)- project UID/QUI/00100/2013 and grant SFRH/BD/78639/2011 -and ENGIEfor financial support (Project ENGIE/IST/UPMC). The authors also acknowledge Laboratoire Catalyse et Spectrochimie (LCS, ENSICAEN) for making possible the execution of the FTIR experiments presented in this work and, in particular, to Professor FrédéricThibault-Starzikand Dr. Vladimir L. Zholobenko for the valuable discussions regarding the interpretation of results from such experiments.

Finally, the authors would like to pay tribute to Alain Toullec, co-author of this work, who tragically passed away last year. 


\section{References}

[1] European Union, website, Summaries of EU Legislation - Reduction of pollutant emissions from light vehicles, http://eur-lex.europa.eu/legalcontent/EN/TXT/?qid=1429879014532\&uri=URISERV:128186, accessed in October 2014.

[2] H. Engerer, M. Horn, Energ. Policy, 38 (2010) 1017-1029.

[3] Y. Traa, B. Burger, J. Weitkamp, Micropor. Mesopor. Mat., 30 (1999) 3-41.

[4] J.N. Armor, Catal. Today, 26 (1995) 147-158.

[5] Z. Sobalik, in: S.L. Suib (Ed.) New and Future Developments in Catalysis: Catalysis for Remediation and Environmental Concerns, Elsevier, 2013, pp. 155-194.

[6] Y. Nishizaka, M. Misono, Chem. Lett., (1993) 1295-1298.

[7] C.J. Loughran, D.E. Resasco, Appl. Catal., B, 7 (1995) 113-126.

[8] H. Ohtsuka, T. Tabata, Appl. Catal., B, 21 (1999) 133-139.

[9] A.P. Ferreira, C. Henriques, M.F. Ribeiro, F.R. Ribeiro, Catal. Today, 107-108 (2005) 181-191.

[10] A.P. Ferreira, S. Capela, P. Da Costa, C. Henriques, M.F. Ribeiro, F.R. Ribeiro, Catal. Today, 119 (2007) 156-165.

[11] J.A.Z. Pieterse, S. Booneveld, Appl. Catal., B, 73 (2007) 327-335.

[12] I.O. Costilla, M.D. Sanchez, M. Alicia Volpe, C.E. Gigola, Catal. Today, 172 (2011) 84-89.

[13] J.A.Z. Pieterse, R.W. van den Brink, S. Booneveld, F.A. de Bruijn, Appl. Catal., B, 46 (2003) 239-250.

[14] J.A.Z. Pieterse, R.W. van den Brink, S. Booneveld, F.A. de Bruijn, in: E. VanSteen, M. Claeys, L.H. Callanan (Eds.) Recent Advances in the Science and Technology of Zeolites and Related Materials, 2004, pp. 2522-2526.

[15] H.Y. Chen, X. Wang, W.M.H. Sachtler, Appl. Catal., A, 194 (2000) 159-168.

[16] O. Gorce, F. Baudin, C. Thomas, P. Da Costa, G. Djega-Mariadassou, Appl. Catal., B, 54 (2004) 69-84.

[17] E.M. Holmgreen, M.M. Yung, U.S. Ozkan, Appl. Catal., B, 74 (2007) 73-82.

[18] H. Decolatti, H. Solt, F. Lonyi, J. Valyon, E. Miro, L. Gutierrez, Catal. Today, 172 (2011) 124-131.

[19] S.T. Homeyer, W.M.H. Sachtler, Appl. Catal., 54 (1989) 189-202. 
[20] B.J. Adelman, W.M.H. Sachtler, Appl. Catal., B, 14 (1997) 1-11.

[21] S.N. Reifsnyder, M.M. Otten, H.H. Lamb, Catal. Today, 39 (1998) 317-328.

[22] A. Trovarelli, Cat. Rev. - Sci. Eng., 38 (1996) 439-520.

[23] H.L. Tidahy, S. Siffert, J.F. Lamonier, R. Cousin, E.A. Zhilinskaya, A. Aboukais, B.L. Su, X. Canet, G. De Weireld, A. Frere, J.M. Giraudon, G. Leclercq, Appl. Catal., B, 70 (2007) 377-383.

[24] Y.-S. Bi, G.-Y. Dang, X.-H. Zhao, X.-F. Meng, H.-J. Lu, J.-T. Jin, J. Hazard. Mater., 229-230 (2012) 245-250.

[25] A.M. de Oliveira, I. Costilla, C. Gigola, I.M. Baibich, V.T. da Silva, S.B.C. Pergher, Catal. Lett., 136 (2010) 185-191.

[26] Z.J. Li, M. Flytzani-Stephanopoulos, J. Catal., 182 (1999) 313-327.

[27] A.B. Gaspar, L.C. Dieguez, Appl. Catal., A, 201 (2000) 241-251.

[28] K.I. Hadjiivanov, G.N. Vayssilov, Adv. Catal., 47 (2002) 307-511.

[29] V. Gruver, J.J. Fripiat, Journal of Physical Chemistry, 98 (1994) 8549-8554.

[30] M. Armandi, B. Bonelli, E. Garrone, M. Ardizzi, F. Cavani, L. Dal Pozzo, L. Maselli, R. Mezzogori, G. Calestani, Appl. Catal., B, 70 (2007) 585-596.

[31] A.M. Bradshaw, F.M. Hoffmann, Surf. Sci., 72 (1978) 513-535.

[32] M. Daturi, C. Binet, J.C. Lavalley, A. Galtayries, R. Sporken, Phys. Chem. Chem. Phys., 1 (1999) 5717-5724.

[33] P.S.F. Mendes, G. Lapisardi, C. Bouchy, M. Rivallan, J.M. Silva, M.F. Ribeiro, Appl. Catal., A, Article in press (2015).

[34] P. Li, Y. Xiang, V.H. Grassian, S.C. Larsen, J. Phys. Chem. B, 103 (1999) 50585062 .

[35] P. Gelin, M. Primet, Appl. Catal., B, 39 (2002) 1-37.

[36] L. Gutierrez, E.A. Lombardo, Appl. Catal., A, 360 (2009) 107-119.

[37] L. Gutierrez, A. Boix, J.O. Petunchi, J. Catal., 179 (1998) 179-191.

[38] S. Capela, R. Catalao, M.F. Ribeiro, P. Da Costa, G. Djega-Mariadassou, F.R. Ribeiro, C. Henriques, Catal. Today, 137 (2008) 157-161. 


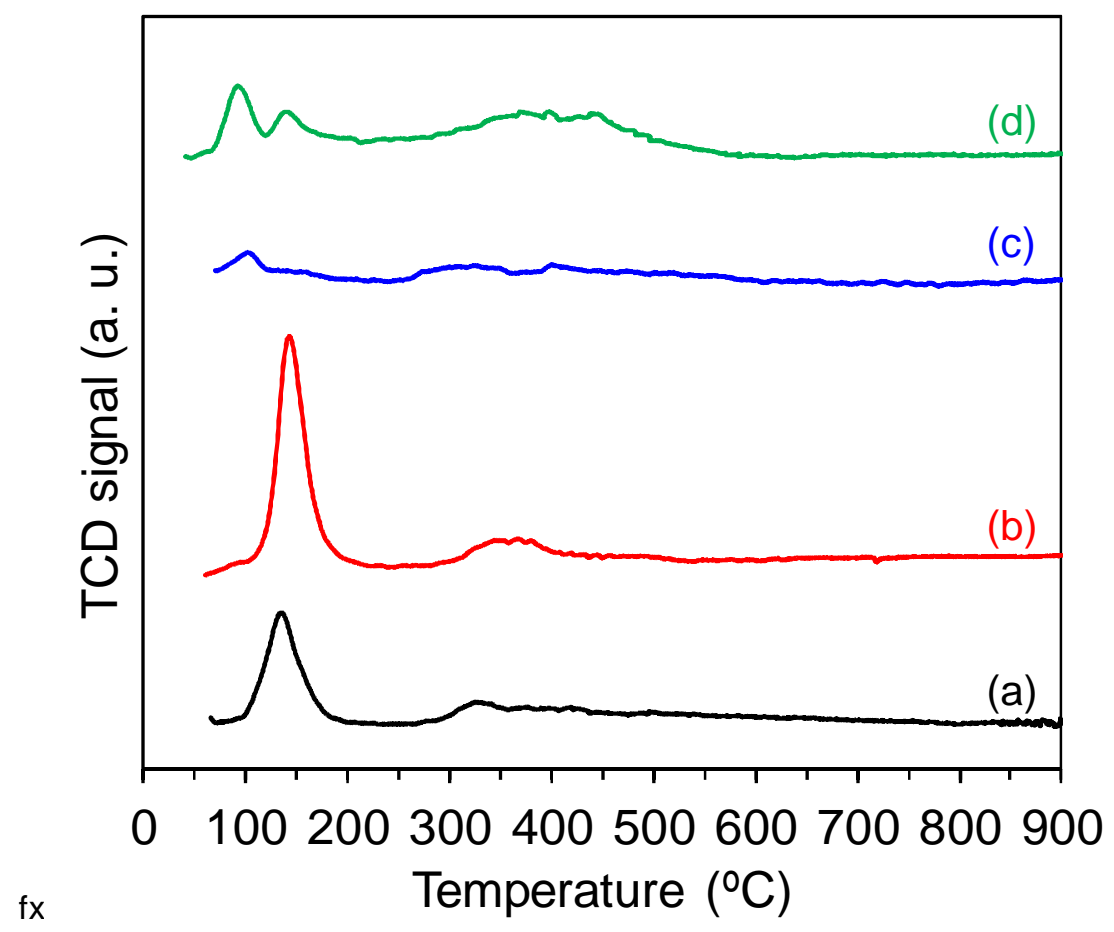

Figure $1-\mathrm{H}_{2}$-TPR profiles: $\mathrm{Pd}(0.3)-\mathrm{HMOR}(\mathbf{a}), \operatorname{Pd}(0.3) \mathrm{Ce}(2)-\mathrm{HMOR}(\mathbf{b}), \operatorname{Pd}(0.3)-\mathrm{HBEA}(\mathbf{c})$ and $\operatorname{Pd}(0.3) \operatorname{Ce}(2)-H B E A(d)$. 

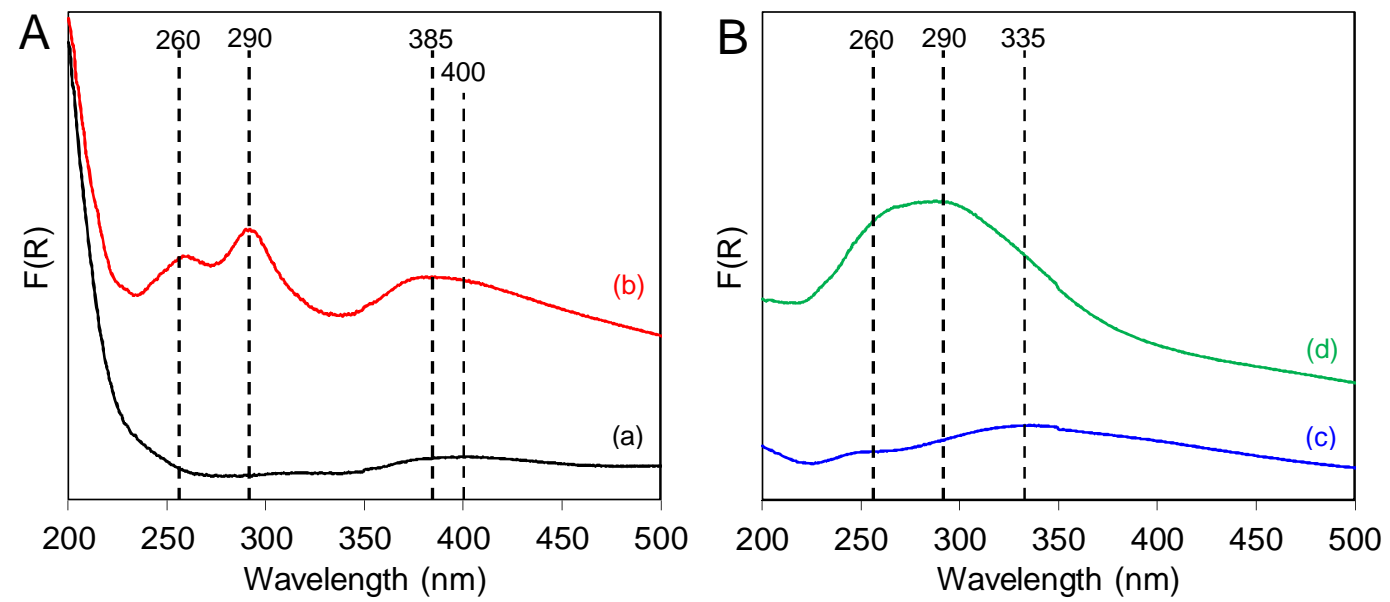

Figure 2 - DRS UV-Vis spectraof MOR (A) and BEA (B) catalysts: $\mathrm{Pd}(0.3)-\mathrm{HMOR}(\mathbf{a}), \operatorname{Pd}(0.3) \mathrm{Ce}(2)$ HMOR (b), Pd(0.3)-HBEA (c) and Pd(0.3)Ce(2)-HBEA (d). 


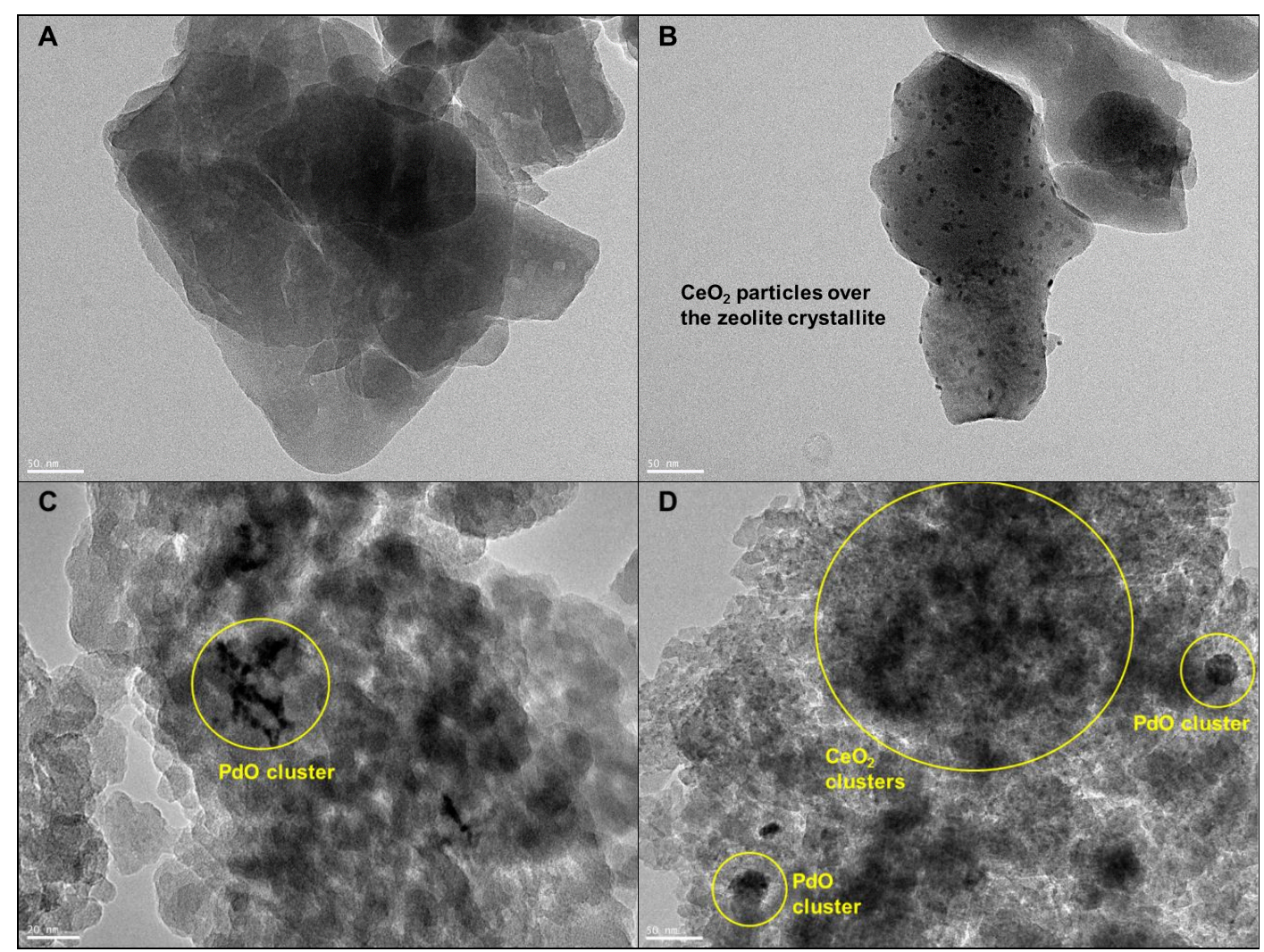

Figure 3 - TEM images: Pd(0.3)-HMOR (A), Pd(0.3)Ce(2)-HMOR (B), Pd(0.3)-HBEA (C) and

$\operatorname{Pd}(0.3) \operatorname{Ce}(2)-H B E A(D)$. 

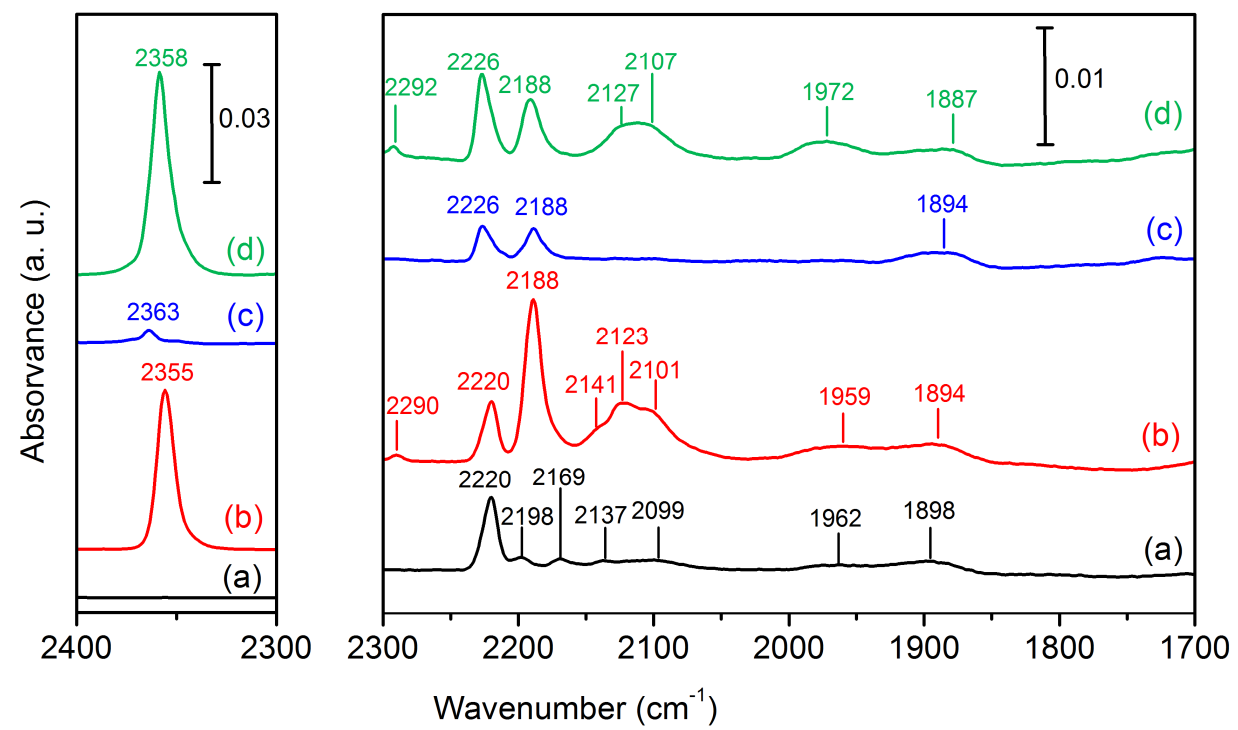

Figure 4 - FTIR spectra of reduced catalysts at room temperature, after 5 torrCO exposure: $\operatorname{Pd}(0.3)$ HMOR (a), Pd(0.3)Ce(2)-HMOR (b), Pd(0.3)-HBEA (c) and Pd(0.3)Ce(2)-HBEA (d). 


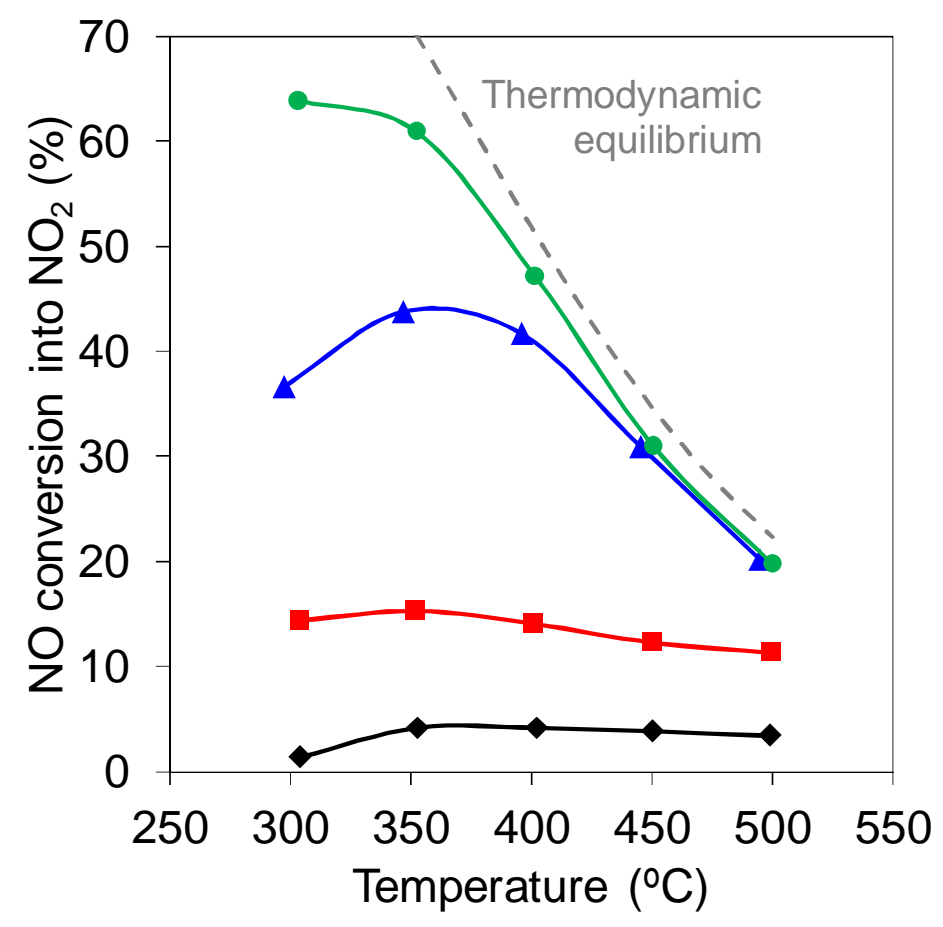

Figure 5 - NO conversion into $\mathrm{NO}_{2}$ of $\operatorname{Pd}(0.3)-\mathrm{HMOR}(\bullet), \operatorname{Pd}(0.3) \mathrm{Ce}(2)-\mathrm{HMOR}(\bullet), \operatorname{Pd}(0.3)-\mathrm{HBEA}(\boldsymbol{\Delta})$ and $\operatorname{Pd}(0.3) \mathrm{Ce}(2)-\mathrm{HBEA}(\bullet)$ with $1000 \mathrm{ppm} \mathrm{NO}, 7 \% \mathrm{O}_{2}$ and GHSV $=40000 \mathrm{~h}^{-1}$. 

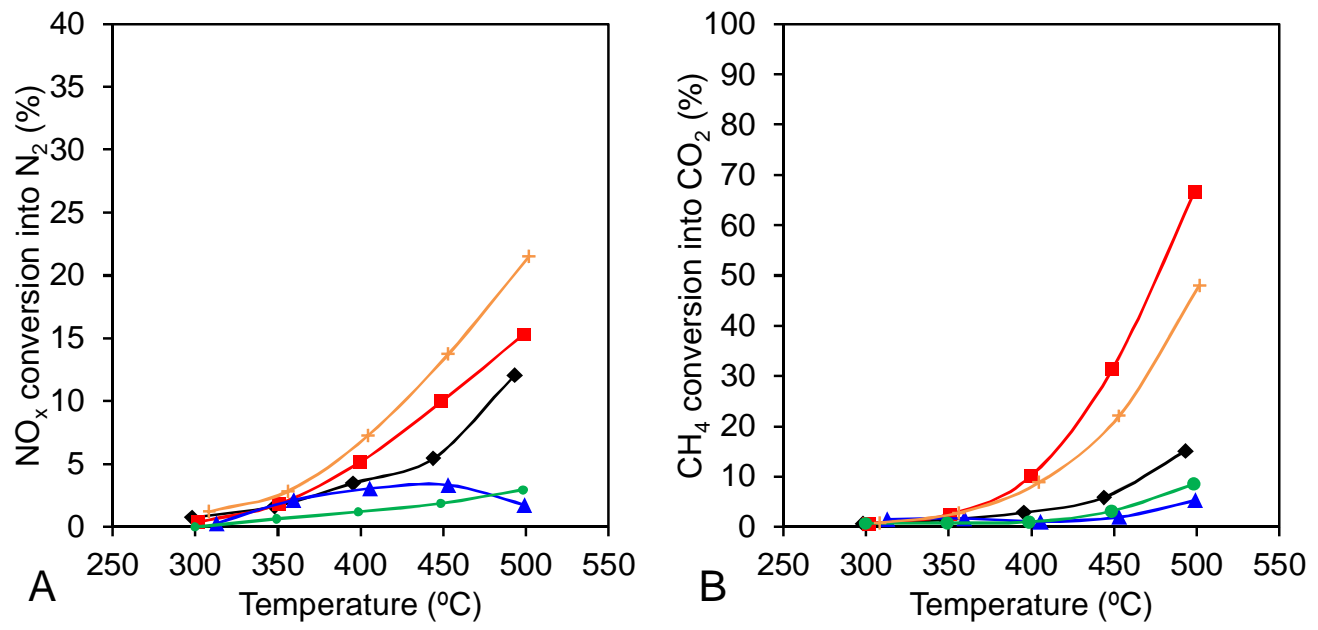

Figure 6 - $\mathrm{NO}$ conversion into $\mathrm{N}_{2}(\mathrm{~A})$ and $\mathrm{CH}_{4}$ conversion into $\mathrm{CO}_{2}(\mathrm{~B})$ of $\mathrm{Pd}(0.3)$-HMOR (^),

$\operatorname{Pd}(0.3) \mathrm{Ce}(2)-\mathrm{HMOR}(\bullet), \operatorname{Pd}(0.3)-\mathrm{HBEA}(\boldsymbol{\Delta}), \operatorname{Pd}(0.3) \mathrm{Ce}(2)-\mathrm{HBEA}(\bullet)$ and dual bed (+) with 1000 ppm $\mathrm{NO}, 1000 \mathrm{ppm} \mathrm{CH}_{4}, 7$ vol. $\% \mathrm{O}_{2}, 2$ vol.\% of $\mathrm{H}_{2} \mathrm{O}$ and $\mathrm{GHSV}=40000 \mathrm{~h}^{-1}$. 


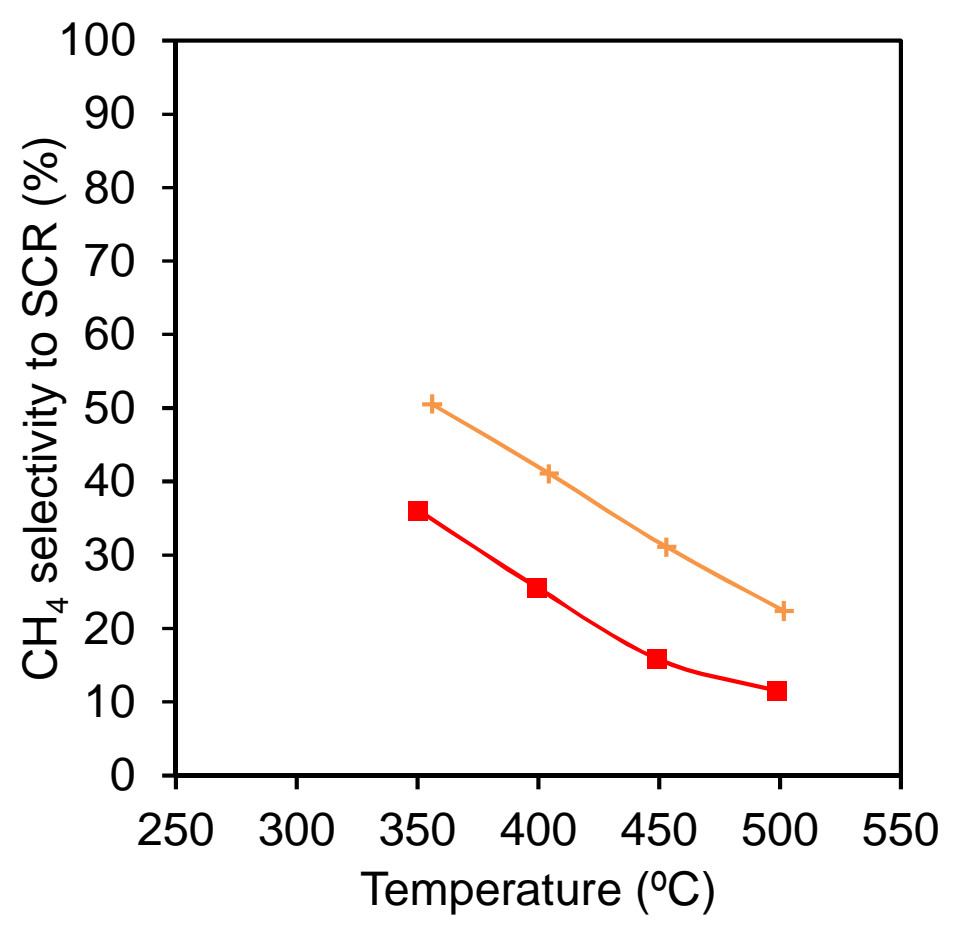

Figure $7-\mathrm{CH}_{4}$ selectivity to $\mathrm{SCR}$ reaction $\mathrm{Pd}(0.3) \mathrm{Ce}(2)-\mathrm{HMOR}(\bullet)$ and dual bed (+) with $1000 \mathrm{ppm}$ $\mathrm{NO}, 1000 \mathrm{ppm} \mathrm{CH}_{4}, 7$ vol. $\% \mathrm{O}_{2}, 2$ vol. $\%$ of $\mathrm{H}_{2} \mathrm{O}$ and GHSV $=40000 \mathrm{~h}^{-1}$. 


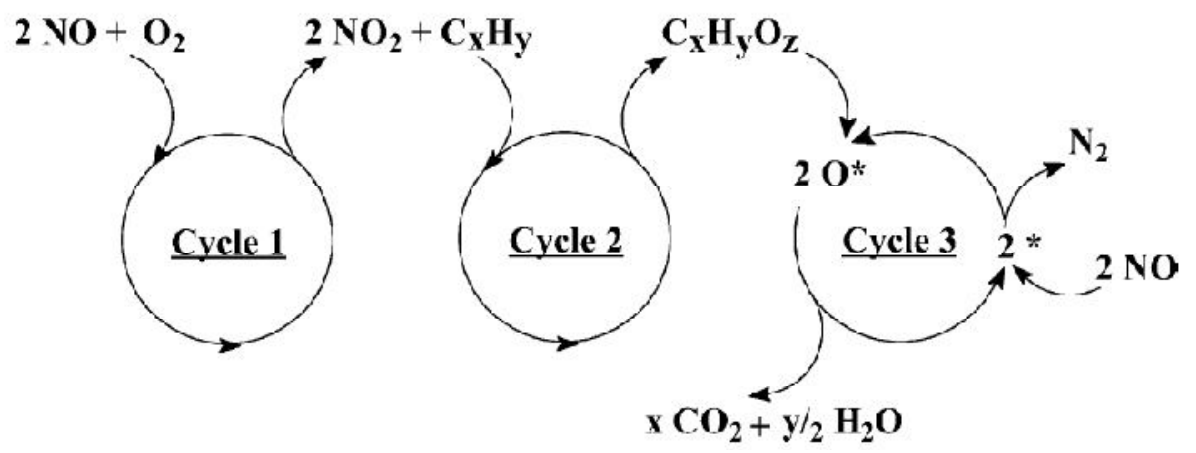

Figure 8 - 3-funtion HC-SCR mechanism (reproduced from [16]). Each cycles corresponds to a function. 


\section{List of Tables}

Table 1 - Comparison of catalytic test conditions and $\mathrm{NO}_{\mathrm{x}}$ conversion between $\mathrm{Pd}(0.3) \mathrm{Ce}(2)-\mathrm{HMOR}$ and other catalysts reported in literature.

\begin{tabular}{|c|c|c|c|c|c|c|c|}
\hline & \multicolumn{4}{|c|}{ Similar formulations } & \multicolumn{3}{|c|}{ Similar $[\mathrm{NO}] /\left[\mathrm{CH}_{4}\right]$} \\
\hline Catalyst & & $\begin{array}{l}.4) \mathrm{Ce}( \\
\mathrm{HMOR}\end{array}$ & -4) & $\begin{array}{c}\mathrm{Pd}(0.2) \mathrm{Ce} \\
(2) \\
\text {-HMOR }\end{array}$ & $\begin{array}{c}\operatorname{Pt}(0.39) \mathrm{Co}(2 . \\
87) \\
-\mathrm{HMOR}\end{array}$ & $\begin{array}{c}\mathrm{Co}(1.7) \mathrm{La}(1 \\
.2) \\
-\mathrm{HMOR}\end{array}$ & $\begin{array}{c}\mathrm{Pd}(0.3) \mathrm{Ce} \\
(2) \\
\text {-HMOR }\end{array}$ \\
\hline $\begin{array}{c}\text { Referenc } \\
\mathrm{e}\end{array}$ & & [14] & & {$[12]$} & {$[37]$} & [36] & This work \\
\hline $\begin{array}{l}{[\mathrm{NO}] /} \\
{\left[\mathrm{CH}_{4}\right]} \\
(\mathrm{ppm})\end{array}$ & $\begin{array}{l}500 / \\
2500\end{array}$ & $\begin{array}{l}240 / \\
1750\end{array}$ & $\begin{array}{l}117 / \\
2260\end{array}$ & $\begin{array}{c}1010 / \\
3300\end{array}$ & $1000 / 1000$ & $1000 / 1000$ & $\begin{array}{c}1000 / \\
1000\end{array}$ \\
\hline $\begin{array}{c}\text { GHSV } \\
\left(\mathrm{h}^{-1}\right)\end{array}$ & $\begin{array}{c}1700 \\
0\end{array}$ & $\begin{array}{c}1700 \\
0\end{array}$ & $\begin{array}{c}1700 \\
0\end{array}$ & 33000 & 30000 & 7500 & 40000 \\
\hline $\mathrm{T}\left({ }^{\circ} \mathrm{C}\right)$ & 375 & 385 & 385 & 500 & 500 & 500 & 500 \\
\hline $\begin{array}{c}\mathrm{NO}_{\mathrm{x}} \\
\text { conversi } \\
\text { on }\end{array}$ & $60 \%$ & $80 \%$ & $\begin{array}{c}100 \\
\%\end{array}$ & $65 \%$ & $36 \%$ & $40 \%$ & $15 \%$ \\
\hline
\end{tabular}

